\title{
Risk management as a determinant of the effectiveness of the quality management system in a building company
}

\author{
Jolanta Harasymiuk*, Janusz Barski
}

\author{
Department of Building Engineering, Faculty of Geodesy, Geospatial and Civil Engineering, \\ University of Warmia and Mazury, Olsztyn, 10-719, Poland
}

*Email: jolanta.harasymiuk@uwm.edu.pl

\begin{abstract}
The aim of this article is presentation of the results of an analysis of quality research on the conditions of an implementation of risk management in Polish building enterprises. The quality research was done on the basis of a participating observation and of an unstructured interview. The interviews were given by the plenipotentiaries of the systems of quality management, as well as by the operating administration of building enterprises. While the participating observation was possible because of the authors' participation in the review of the management in in the role of advisers. The newest edition of the ISO 9001 standard from October 2015 introduced important changes in the field of formalised approach to risk management, which $\mathrm{m}$ present a problem to many building businesses that have not dealt with this issue in a detailed manner so far. The article characterizes risk in a building company, it depicts the process of risk management and its constituent elements, and it proposes the range of process documentation fulfilling the requirements of the standard.
\end{abstract}

Keywords: risk, risk management, quality management system according to the ISO 9001:2015 standard, effectiveness of system, building company.

\section{Introduction}

Preparation and certification of formalized quality management systems in Poland were initialized in 1993 in big building enterprises. It was only with time that the subjective systems began being used in the service sector, and in its framework also in the building business. The reports which have been made since 1995 on the order of the International Standardization Organization reveal that in Poland as of 2014 the number of issued, valid certifications amounted to 9608, whereas in China - 342800. The coefficient of the saturation of ISO 9001 certificates, understood as the number of issued certificates for a million of inhabitants is better for Poland, in the end of 2015 it stood at 249, whereas in China 246 [1]. In the literature on the subject it is pointed out that the added value of implementation and certification of the quality management system is among others the increase of the operation effectiveness of a business. According to the ISO 9000:2015 standard [2], an effectiveness is "a relation between the obtained results and the used resources" [2]. It means that, e.g. a process/system is effective, when it shows the required volume of the expenditures used in relation to the obtained results [3]. The research reveals that Polish enterprises have difficulties in obtaining such advantages. This situation pertains also to building enterprises, which may be the reason for the lack of interest in implementation of the standardized solutions in quality engineering. According to one of the recognized certification units in Poland, the number of certificates issued for enterprises of the building sector since 1993 to the first quarter of 2016 did not exceed $0.2 \%$ of their total number. The reasons for that were the inner and outsider conditions. To the outside reasons belong the low profitability of building production which impels the lowering of production costs, among them also of the expenditure on training and on purchase of the software supporting the quality management, the continuous changes of legal regulations, which discourage the management to pan the operation and development in a long term perspective and to determine the strategy of an enterprise, the dispersity of building sites and arising from it difficulties to adjust the quality systems in the organizational structures of an individual building undertaking. Among the outside conditions, it can be distinguished: the lack of acceptance by the productive and managerial units of enterprises, the unwillingness of the 
engineering staff to make additional efforts which exceed the range of their duties and to change the habitual routine of work, the unwillingness to resign from existing privileges, uncertainty of the results of the implemented changes, and the awareness of their weaknesses issuing e.g. from the incompleteness of the system solutions with regard of effective planning of building work. The imbalance of the demand and supply of building work results in hard competition of building enterprises. The decisive factor of placing an offer is the price. In order to present a fair price offer the contractor should know and implement the principles of risk identification and evaluation. The aim of the article is to present the results of the quality research concerning the implementation of risk management in operation of small and medium enterprises.

\section{Risk as an element of activity of a building contractor}

Risk is indispensably connected to the activity of building businesses. Defined as a possibility of making a loss, it accompanies every building work [4,5]. This risk is partly similar to the risk occurring in a typical productive plant, but in a part it shows differences issuing from a specific investment situation. Because there are no two identical building investments, and even if they are realized on the basis of a typical building project, they differ in the time of completion, locality, financing structure, cooperation on the building site. Thus different results and risk can be expected from seemingly similar building undertakings. Following $[6,7,8,9]$, the authors view risk as a function of probability of threat occurrence and the result of this threat if it occurs. A threat is an eventuality that undesired event or circumstances occur, which may result in losses in the realization of a building task. The result is an effect of an action of unwanted phenomenon, that is a loss for a building contractor.

\section{The risk management in the ISO 9001 standard}

The presently in force ISO 9001:2008 standard [10] does not include all the deands which are important for functioning of a building enterprise. Building realization is a specific kind of economic activity, which beside the significant social mission of covering the housing demands, it is burdened with an over-average level of risk. This aspect is not addressed in the requirements of the ISO 9001:2008 standard [10], which results in incoherence of the quality management system with the standard, although there is a formal consistence between the two, and hence the system proves ineffective. The new edition of the ISO 9001 standard from October 2015 proposes the approach based on risk, which in a sense substitutes the process approach. The issues of risk management are emphasized almost in each of the ten chapters of the norm. the consequence of a such situation is a need for the systematic approach to risk management. The ISO 9001:2015 standard [10] does not determine the requirements of an implementation of an individual process of risk management or a preparation of a documented procedure concerning this issue. In building practice, the identification, analysis and risk evaluation without the risk documentation seems to be unrealistic, because they are standard proceedings which go before the calculation of the price of building work or assessment of processes.

The process of risk management is a systematic set of conduct principles aimed at protecting a building contractor against the unwanted results of threats or at minimalizing the probability of their occurrence. The risk management in processes consists of a number of cyclically repeated activities, such as:

1. identification - determination of potential threats in realization of processes;

2. assessment - estimation of occurrence of threats and their consequences;

3. determination of the level of accepted risk - the evaluation if the sort of risk in question is acceptable for the building contractor (not requiring supervision), or unacceptable (reverse characteristics). The acceptable level of risk may be different depending on the range of the projected building work and the scale of problems occurring in the realization; 
4. determination of the priority of risk factors - identification of risks implicating the gravest results (the risk of exceeding the deadline, the risk of the failure of reaching the required quality of building work);

5. handling the identified risk - determination of an action plan towards the risk exceeding the acceptable level (reduction, transfer of risk), keeping records concerning the achieved results.

In order to manage effectively the risk in processes, there should be defined its make-up elements such as: objective, correlations with other processes, input and output, the range of required actions and of process control, the principles of assessment of the state of output elements (Fig.1).

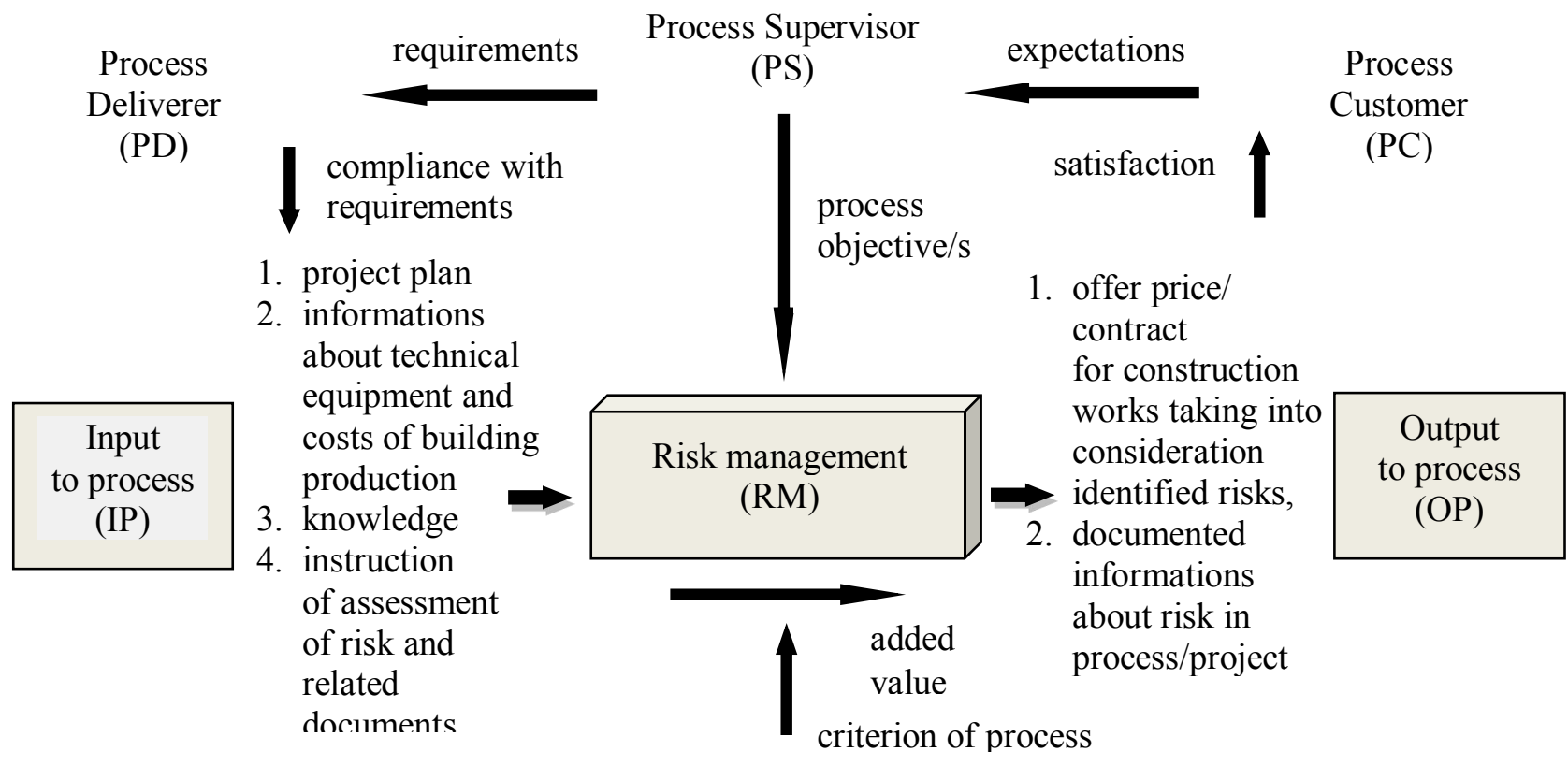

Fig. 1. The elements of risk management in basic processes of a building company (prepared by the authors).

In table 1, the elements of the process of risk management are presented at the stage of preparing an offer and making a contract for building work

In the building sector, risk is associated with the threats which affect the position of a building contractor (exceeding the deadline, increase of costs). Considering the requirements of the ISO 9001:2015 standard [11], the analysis of threats must be accompanied with the identification of opportunities and the assessment of the possibility of occurrence of advantageous events for a building company [12]. An example of a card of estimation of the risk and opportunities understood as benefits issuing from improvement and development were shown in table 2.

\section{Conclusions}

The risk management is not a new notion and occurs in practice of each economic activity [13], but the building sector should analyze it in detail because of its specific character.

The requirement of a formalized approach to the risk management, which is present in the ISO 9001:2015 standard fills the lack of the quality management systems.

The basic condition for the effective risk management is seeing it as a process which will ensure the appropriate coordination of required make-up elements. In the authors' opinion the risk management should be a part of the basic processes of a building company. With such approach the labor-intensiveness of the risk assessment is reduced and the acceptance of the system activities aimed at its reduction are more welcomed by the enterprise personnel.

It may depend on the solidity in the approach of risk management if there are no obstacles in realization of the undertaking. 
Table 1. Risk management in the process of preparing an offer and signing a contract for building work (prepared by the authors).

\begin{tabular}{|c|c|}
\hline Objective & Minimalizing of risk in process of preparing an offer and signing a contract \\
\hline $\begin{array}{l}\text { Relations with other } \\
\text { processes }\end{array}$ & $\begin{array}{l}\text { The process is related to: } \\
\text { 1. in input - to outer environment and all the processes of a building business; } \\
\text { 2. in output - to all the processes connected with information and decision making. }\end{array}$ \\
\hline Elements of input & $\begin{array}{l}\text { Documented information - specification of important conditions of an order, technical } \\
\text { specification of realization and acceptance of building work, project documentation, } \\
\text { pre-assessment of work, data concerning the means of production in an enterprise and } \\
\text { their use. } \\
\text { People involved in risk identification and assessment - technological-productive } \\
\text { manger, plenipotentiary for the quality management systems, head of a building site, } \\
\text { heads of staff units. } \\
\text { Technical means - telecommunication and computer equipment making the } \\
\text { communication easier. }\end{array}$ \\
\hline Range of activity & $\begin{array}{l}\text { 1. Imitation by the technological-productive manager an inner ID-SZJ/I/01 document, } \\
\text { known as "The card of threats and opportunities assessment" } \\
\text { and sending it to the chosen specialists and heads of organizational units } \\
\text { of the enterprise with the request to fill it up. } \\
\text { 2. Determination by the board of directors the scale of probability and the results. } \\
\text { 3. Estimation by the authorized people the occurrence of the probability and } \\
\text { the effects of the threats identified or in the inner document } \\
\text { ID-QMS/I/01 in relations to the building contract along with the detailed reasoning } \\
\text { (if required). } \\
\text { 4. Handing over by the technological-productive manager the filled inner document } \\
\text { ID-QMS/I/01 to the plenipotentiary for the quality management system } \\
\text { with the aim of determining the level of the total risk of the contract. } \\
\text { 5. Presentation of the identified risk for acceptance of the management of the } \\
\text { enterprise. } \\
\text { 6. Choosing by the management appropriate to the scale of threats/opportunities } \\
\text { strategies conducting the risk. } \\
\text { 7. Handing over "The card of threats and opportunities assessment" to heads, and/ } \\
\text { or specialists in the organizational units of the enterprise, where supervision of the } \\
\text { risk will be necessary. }\end{array}$ \\
\hline Responsibility & The management of an enterprise. \\
\hline Conduct principles & Instruction: assessment of risk. \\
\hline $\begin{array}{l}\text { Documenting } \\
\text { of a process }\end{array}$ & $\begin{array}{l}\text { The card of threats and opportunities assessment, risk matrix, threats scales, } \\
\text { probabilities and effects of risk, definition of an acceptable risk, description } \\
\text { of tackling in the case of identification the gravest risks (decision path). }\end{array}$ \\
\hline $\begin{array}{l}\text { Monitoring } \\
\text { of process } \\
\text { progression }\end{array}$ & Assessment of management, internal and external audits. \\
\hline $\begin{array}{l}\text { Requirements } \\
\text { concerning the output } \\
\text { elements }\end{array}$ & A price offer meeting the demands of a investor. \\
\hline \begin{tabular}{|l|l|} 
Effectiveness \\
coefficient
\end{tabular} & $\begin{array}{l}\text { In } 2_{\text {QMS }}-\text { the share of offers which were finalized by signing a contract on building work } \\
\text { to the total number of offers placed in the period of the analysis. }\end{array}$ \\
\hline
\end{tabular}


Table 2. A template of the inner document ID-QMS/I/01 "The card of threats and opportunities assessment" (source: prepared by the authors).

\begin{tabular}{|c|c|c|c|c|c|c|c|}
\hline 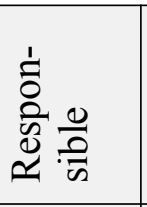 & $\begin{array}{c}\text { Threats } \\
\text { (Z) }\end{array}$ & $\begin{array}{c}\text { Probabili-ty } \\
\text { (P) }\end{array}$ & $\begin{array}{l}\text { Result } \\
\text { (S) }\end{array}$ & $\begin{array}{l}\text { Risk } \\
\mathrm{P} \times \mathrm{S}\end{array}$ & $\begin{array}{c}\text { Reasoning for } \\
\text { the } \\
\text { assessment } \\
\text { of risk }\end{array}$ & Corrections & Prio-rities \\
\hline 1 & 2 & 3 & 4 & 5 & 6 & 7 & 8 \\
\hline \multirow{6}{*}{ 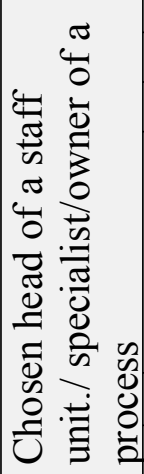 } & & & & & & & \\
\hline & & & & & & & \\
\hline & & & & & & & \\
\hline & $\begin{array}{l}\text { Opportu- } \\
\text { nities } \\
\text { (O) }\end{array}$ & $\begin{array}{l}\text { Probabili-ty } \\
\text { (P) }\end{array}$ & $\begin{array}{l}\text { Result } \\
\text { (S) }\end{array}$ & $\begin{array}{c}\text { Opportu- } \\
\text { nity } \\
\text { P x S }\end{array}$ & $\begin{array}{l}\text { Reasoning for } \\
\text { the } \\
\text { assessment } \\
\text { of opportuni- } \\
\text { ties }\end{array}$ & Remedies & Prio-rities \\
\hline & & & & & & & \\
\hline & & & & & & & \\
\hline
\end{tabular}

\section{References}

1. Information on http://www.iso.org.

2. ISO 9000:2015 Quality management systems - Fundamentals and vocabulary.

3. M. Jasiulewicz-Kaczmarek: Lecture Notes in Computer Science, Vol. 5624 (2009), 153-161.

4. M. Bętkowski, A. Pownuk: Szacowanie ryzyka kosztowego procesu budowlanego $\mathrm{z}$ wykorzystaniem zmiennej losowej o parametrach rozmytych w oparciu o metodę Monte

- Carlo, Konferencja naukowo - techniczna „Budownictwo polskie w rok po wstąpieniu do Unii Europejskiej”, Gdańsk 9-11 June (2005), 13-22.

5. H. Gołaś: Lecture Notes in Computer Science, Vol. 9178 (2015), 270-279.

6. C., L. Pritchard: Zarządzanie ryzykiem w projektach. Teoria i praktyka. Management Training \& Development Center, (2001).

7. A. Skorupka: Archives of Civil Engineering, Vol. 51, No. 4, (2005), 647-662.

8. A. Radomska-Zalas: Studies \& Proceedings of Polish Association for Knowledge Management, No. 41 (2011), 185-196.

9. Gołaś H., Mazur a., Mrugalska B.: Metalurgija, Vol. 55, Iss. 4 (2016), 811-814.

10. ISO 9001:2008 Quality management systems - Requirements.

11. ISO 9001:2015Quality management systems - Requirements.

12. A. Kleniewski: Problemy Jakości No 2/2016.

13. M. Jasiulewicz - Kaczmarek, P. Drożyner: Maintenance Management Initiatives towards Achieving Sustainable Development, [in.] P. Golinska et al. (eds.): Information Technologies in Environmental Engineering Environmental Science and Engineering, Springer - Verlag Berlin Heidelber, (2011), 707-721. 